\title{
Do We Need a New Direction for Managing a Multi-Stakeholder Co-operative? A Critical and Theoretical Reflection on Why Aspirations Sometimes Fail
}

Esther Awotwe, PhD candidate, University of Saskatchewan, Canada

Simon Berge, PhD, University of Winnipeg, Canada

Peter Davis, PhD, FRSA, CFCIPD, University of Leicester School of Business, United Kingdom

\begin{abstract}
Central to this paper is a case study examining stakeholder management in a multi-stakeholder co-operative firm from Ontario, Canada focused on the role of the Democratic Member Control principle and operational interactions in finding common ground among stakeholders. The actor's aspiration in the case study is for economic democracy and social inclusion and the development of a local sustainable economy providing food security for all. The authors' first claim is that this case study, whilst a modest one in itself, is representative of many small bottom-up initiatives taken by people anxious to make a difference in their communities informed by co-operative values and principles. Although there have been notable success stories such as the ones in Mondragon Spain and Kobe Co-op in Japan, even these examples have met with challenges and questions of long-term viability in the context of globalisation (Basterretxea, l., et al., 2020).
\end{abstract}

The case study results indicate that: a) stakeholder relations via operational interactions need to place greater emphasis on market and other factors emerging in the business environment when identifying stakeholder's needs, and b) while necessary, the reliance placed on incorporating the Democratic Member Control principle within the firm's governance is not enough to ensure business growth and development. Our paper proposes an operational network based model of business development that draws heavily on the ideas of John Burgoyne's distinctive model of a Learning Organisation. Thus, we suggest the cooperative requires an approach that draws more on a co-operative value-based use of management tools, particularly marketing and consumer surveys, to gather essential market information in its operational interactions with stakeholders.

Esther Awotwe is a PhD candidate at the Johnson Shoyama School of Public Policy, University of Saskatchewan. Her focus is on building and creating sustainable communities.

Simon Berge, PhD, is an Associate Professor at the University of Winnipeg in the Business and Administration Department. The focus of his research is on social enterprises, co-operatives and leadership.

Peter Davis, PhD, FRSA, CFCIPD, is an Honorary Fellow at the University of Leicester School of Business and an Adjunct Professor in co-operative management education and development, at the Sobey School of Business, Saint Mary's University, Halifax, Canada. His central research interests are focused on problems of co-operative and mutual sector philosophy, values, economy, management, strategy and development in the context of globalisation, liberalisation and climate change.

Keywords: Co-operative Business Development, Co-operative Social Capital Management, Governance, Learning Organisation, Networks, Stakeholder Engagement.

\section{Introduction}

Donaldson and Preston (1995) suggest there is a lack of evidence linking instrumental stakeholder theory to achievement of business objectives. The case study presented in this paper confirms that this connection remains problematic even where the business model is a co-operative one. Davis (2001) suggests one of the advantages of a co-operative organization is that stakeholder conflicts are less acute than in their for-profit counterparts. He accepts co-operatives must generate a surplus to meet the firm's depreciation and development costs like all other firms, but they do not have to focus on paying dividends on shares to appease a shareholder group.

Correspondence address: Simon Berge, Department of Business and Administration, University of Winnipeg, Winnipeg, Manitoba, Canada. s.berge@uwinnipeg.ca 
Ackoff (1981) suggested a multi-stakeholder organization focuses on serving the interests of the component parts of the organization. This concept overlooks that in a market-governed business key stakeholders are interacting within competitive market exchanges. Davis (2004) suggested extending co-operative business strategy to incorporate the members' association linked with community activism informed by the philosophies of Intellectual Capital Management (Edvinsson, Leif and Malone, Michael, S.1997) and Learning Organisations (Burgoyne, 1995). This model suggests a process and methodology for mobilising local tacit knowledge transfer to the co-operative business from within its markets and community generating new co-operatives responding to community needs (Nonaka and Takeuchi, 1995).

S. Sacchetti and Tortia (2008) suggest the nature of multi-stakeholder co-operative needs to be considered from the viewpoint of a network of co-interested and co-motivated actors. This concept of a networked group of actors is further strengthened by the social ties that the networked actors have with each other (Granovetter, 1983). These ties are constantly evolving, building on interconnections as well as connections external to the organization ( $\mathrm{S}$. Sacchetti, Tortia, \& Tortia, 2016). It is the management of these changing interconnections that make the multistakeholder organizational model uniquely suited to stakeholder management theory (Sacchetti \& Torita, 2014). Our case study suggests these networks should be providing the very outcomes Davis' (2004) model aspired to but are theoretically misplaced within internal organisational frameworks.

Co-operative businesses operate in a market framework (Davis, 1999) in which the actual inclusionary practices resulting in the 'reciprocating behaviours and common social goals' (Ben-Ner \& Putterman, 1999; S. Sacchetti \& Sugden, 2003; Sacconi, 2011) are actually found rather than in governance processes. The acceptance of the mission, vision and principles of the multi-stakeholder co-operative must be implemented and understood in response to a network arising in the co-operative marketplace, its competitors, customers and suppliers. Our paper will propose that applications of co-operative value based management to realise co-operative multi-stakeholder goals can best be achieved utilising John Burgoyne's model of a Learning Organisation (Burgoyne 1995) but with two important caveats. First, the model must be modified to fit the co-operative not the other way around and, secondly, it must be recognized that Burgoyne's model is not enough. All co-operatives must not simply listen and reflect on what is coming in, as for small co-operatives, as in the case study, the boundaries will be too narrow a source of data. Co-operatives must make it a central part of listening that they reach out to gather information not just from supporters but from a wide spectrum of potential customers and members and always check out their competition.

Burgoyne's model provides the informational content and networked communications, blending the tacit knowledge of informal market processes with the formal operational structure's explicit formal knowledge (Nonaka and Takeuchi, 1995) to create a co-operative business information and business relationship management model based on communicative rationality, trust and reciprocity grounded in stakeholder needs as argued for by $\mathrm{S}$. Sacchetti \& Sugden (2003) and Zamagni (2012). Co-operative purpose is protected and the co-operative business embedded in its community through member engagement as advocated in Davis' (2004) Social Capital Management framework grounded in co-operative ownership and values.

The focus on individual stakeholders as a component of the firm's governance in co-operatives, as in the mainstream, is generally seen through a Kantian lens:

This means each stakeholder group has a right to be treated as an end in itself, and not as means to some other end, and therefore must participate in determining the future direction of the firm in which [it has] a stake (Evan \& Freeman, 1988, p. 97 emphasis not in original).

This Kantian approach emphasising governance rights is correct in principle as far as governance goes but cannot be the basis of operations that must be driven by market requirements not institutional ones. Operational strategies and processes exist to implement organisational mission, vision and policy. Operational strategies must use and be led by their own networked and market-based information flows to manage the mission, vision and policy development. It's not a case of either / or but the relative requirements of both.

Turnbull (1997, p. 19) focuses on some possible reasons stakeholder relationships are neglected, or prove difficult, within co-operative firms including: a) the cultural hegemony of competitive values, which inhibits those with co- 


\section{Do We Need a New Direction for Managing a Multi-Stakeholder Co-operative? A Critical and Theoretical Reflection on Why Aspirations Sometimes Fail}

operative values from promoting participation outside a business in case they are seen to have questionable business acumen; b) industry and legal concerns in establishing formal relationships with customers and suppliers, and c) lack of experience and knowledge of how to structure value adding relationships with external stakeholders. The historical approach of stakeholder relationship management presented by Evan and Freeman (1988) is reiterated in Turnbull's (1997) view that there exists a competitive value system within relationships in which individual stakeholder groups vie for control over the firm's outcomes undermining co-operative values.

Davis (2018a), however, argued that it's not a question of eliminating conflict in a co-operative context but of establishing the management and leadership culture and institutional framework for just conflict resolution that cooperative values, vision and ownership enable.

Turnbull's (1997) final point of lack of experience in managing organizational structures that take into account multistakeholder relations may be on point as the formal constitution of multi-stakeholder co-operatives are a relatively new organizational structure in Canada. The majority of multi-stakeholder, or solidarity, co-operatives found in the Province of Quebec are all relatively new (Lund, 2011). However, this concentration on the legalistic and formal misses the point. The co-operative's business viability depends at least as much on the quality of its external market relationships.

Davis (1999), drawing on the UK Co-operative Bank success during Terry Thomas' leadership, pointed out that marketing tools directed at the mass customer or membership base, when informed by co-operative values are critically important and effective not simply for customer relationship management but for organisational governance itself. Again, it's not a question of either / or; both internal and external relationships are important but co-operative academic and management literature on governance focuses much too much on the former. What this literature ignores is that co-operative values were designed to operate in the marketplace and that co-operative ownership and values should in theory make co-operatives better able to respond to that market than capitalist businesses (Davis 1999).

This is not happening, however, because co-operative institutional frameworks, critical for managing the outcomes of market relationships, are not appropriate for the processes of managing the market relationships themselves. Many co-operators become anxious that co-operative values being so different in principle to the values of capitalist firms will be undermined by market forces. But in Burgoyne's version of a Learning Organisation, market and other environmental intelligence is used to support strategies that remain focused on first principles and core values. Burgoyne insists,

Higher levels of learning are, after all, more about finding ways of changing the world and the interaction with it to maintain core values rather than to being swept along, if one is lucky and skilful, by adapting to externally driven change. (Burgoyne, J. 1995, p. 23)

Co-operators must first learn to listen and understand where community is in order to begin the process of transformation to a better more sustainable, just and democratic one.

It's also a mistake to ignore the importance of professional leadership as an important factor in co-operatives' organizational efficiency and membership engagement. The most successful credit unions and co-operatives successful, that is, both as co-operatives and as financial services or agricultural service providers - are ones with active value based professional managers committed to co-operative values. Tragedies like the privatization of the Canadian Wheatpool and the Bankrupting of the UK Cooperative Bank were the result of co-operatives succumbing to a culture of 'MBA managerialism' rather than nurturing a co-operative value based management grounded in an ethical agency contract (Neto, S. B., 2012 and Davis P 2018b). The record shows that democratic governance procedures in themselves are no guarantee against this threat particularly in large co-operatives (Davis, 2014).

The tension identified across the history of working class organizations between an incompetent and inactive membership and a skilled leadership (Michels, R. 1911) has often, in a co-operative context, been presented as a justification for direct worker collective control, but this is a mistake at two levels. First, such collectives can never become big enough for the scale of economic intervention to be more than marginal in terms of transforming 
economic relationships. Second, the collective consensus model is no guarantee of democratic process dependent as it is on the social psychology and group dynamics of its members. Such 'self-governing collectives' can easily end up an informal patriarchy or matriarchy. It's never a question of whether there is leadership in human groups and organizations. Rather it is whether leadership is accountable servant leadership (Davis, P. 1999, p. 22) or leadership that can hide behind the collective or the elected board, remaining unaccountable for its strategic choices or the policies that it has imposed by stealth, weight of personality or better access to information. These problems for cooperatives exist whether they have a formal multi-stakeholder representation, a worker collective or the more standard civil service model of governance. The case study is interesting both for the claims it makes to be a multistakeholder co-operative and for claims about the superiority and effectiveness of this model of governance. However, managerialism as a subversion of co-operative purpose was clearly not a problem in this case study. But if we want to measure the effectiveness of governance in the case study, we need to be clear as to how co-operative purpose is to be defined both as presented in the specifics of the case and in general.

\section{What is the co-operative purpose?}

Lund (2011) argues that in Europe and Canada, multi-stakeholder co-operatives are typically formed to pursue primarily social objectives. This is inaccurate at a number of levels. First, and most obvious, all co-operatives are multi-stakeholder if they remain true to the values of inclusivity and community. There are lifestyle co-operatives whose principal focus is on how small groups can live and work in a sustainable and fraternal fashion on the basis of consensus decision making. Such groups are as valid as any other co-operative endeavor but not more so. Individual visionary leaders concerned with economic justice not personal gain populate the history of co-operation in Canada and across the world. Often, but not always, such charismatic figures are great founding idealists. Research (Fairbairn, MacPherson, \& Russell, 2000) illustrates the economic and social goals behind these leadership visions of socially and community-grounded economic organisations. The original co-operatives in Quebec utilized a credit union business model to help local farmers gain access to credit and avoid usury fees from the standard banking models of the time. The development of the Caisse Populaire provided an economic benefit to local farmers at the expense of conventional corporate measures such as excessive profit and growth.

Prairie farmers had been locked into a monoculture, staple production system that squeezed grain producers to the point of subsistence living. Agricultural marketing agencies, farm supply co-operatives, and eventually the wheat pools, would offer more economically just outcomes through democratic ownership not to destroy the market system but to give farmers better leverage and access in the market system (Brym \& Sacouman, 1979; MacPherson, 1979).

Many contemporary co-operative initiatives may well be the outcome of the remaining influence and idealism of George Keen, one of the leading builders of the co-operative movement in Canada, whose consumer theory of cooperation de-emphasized the over production of goods through economies of scale which Keen believed brought about inflated prices, conspicuous consumption, misleading advertising, exploitative practices and class warfare. Keen advocated controlling the resources of a community through a democratic, co-operative model negating mass production and re-focusing production to community or stakeholder needs (Keen, 1949).

The Rochdale Pioneers as early as 1844 envisioned long-term goals for establishing co-operative communities (Gide, 1922) which remain valid today. However such visions remain unrealised because co-operatives have either: a) operated in a market successfully and then forgotten why they were formed; or else b) have tried prematurely to establish an alternative model alongside the marketplace in the context of a capitalist structure bigger and better resourced and crucially better at communicating in the marketplace.

Looking specifically at development of co-operatives in the Province of Quebec, we can see the strong link to the Catholic Clergy within the Caisse Populaire, reinforcing the close-knit identity of the French Catholic communities in small towns and rural areas (Rudin, 1990). According to lan Macpherson (1979), the idea of helping French Catholic communities did not even originate from the community at large, but from the elite within the community. Macpherson outlined how Caisses Populaires were run by lawyers, bankers and businessmen. These groups were founded and led by men and women motivated by the ideals of Catholic Social Doctrine, which since the latter part of the $19^{\text {th }}$ century have supported co-operative and trade union development globally as appropriate tools for 


\section{Do We Need a New Direction for Managing a Multi-Stakeholder Co-operative? A Critical and Theoretical Reflection on Why Aspirations Sometimes Fail}

improving economic justice. The fact that the leadership of financial service co-operatives was in the hands of professional and educated people was only prudent and also a fundamental principle of organisation in the Raiffeissen Credit Union Movement in Europe. Left to their own devices, the poor fell as easy prey to unscrupulous usurers, often losing what little property they had (F.W. Raiffeisen, $1818-1888$, p. 4).

In fact, developing the professional skills of board members has always been a key concern of all co-operative Human Resource Development (HRD) programmes. We shall argue in our penultimate section that Burgoyne's version of a Learning Organisation with its focus on environmental data, particularly market data, inflows does not obviate the need for professional management or democratic governance in co-operatives, but ensures that both receive a 'bottom up' continuous feed of market information as it evolves on the ground day to day. As our earlier quote from Burgoyne makes clear, his model is far from being seen as merely reactive to 'blind' market forces.

Firstly, a co-operative that is true to their principles (Mercer, T.W. 1931 and Watkins, W. P. 1986) responds to market forces to deliver services needed by the members. Secondly, as far as circumstances permit, the co-operative steers toward the long-term vision of co-operatives to permanently transform the economic relationships that left small farmers, workers and all poor consumers in disadvantaged dependent and marginalised conditions. Thirdly, cooperatives aim to raise the levels of fraternity, solidarity and inclusivity in terms of educational and cultural activities to ensure members have the personal and spiritual resources for their personal growth and to support the growth of their community and society. Of these strands of activity the fact that most co-operatives rarely get beyond the first and hardly ever consider the second is largely due to their neglect of the third (Goedhart, G.J.D.C, 1928 (President ICA 1926-1927)).

\section{The Case Study: Research Design and Methods}

The multi-stakeholder co-operative was part of the On Co-op database of Ontario co-operatives. On Co-op is the trade association responsible for advocating on behalf of co-operatives across the province representing 1300 cooperatives registered in Ontario (On Co-op, 2013). The co-operative in this study represents a multi-stakeholder, not-for-profit co-operative located in a lower-income neighborhood of a large urban centre in the Golden Horseshoe region of Ontario. The co-operative maintains categories of consumers including eaters (urbanites that seek out local food or quality food products - as defined by the co-operative manager), producers, workers, and community partners.

Over 5 years in operation (2008 -2013), the co-operative became an established retailer promoting food security initiatives including a Farmers' Market, Community Cannery, Community Shared Orchard, Food Mapping Project, and a Retail Store. These initiatives provided a revenue stream for the co-operative of just over $\$ 50,000$ a year in gross sales revenue with a membership of 600 in 2013.

The co-operative's operations help the stakeholders to determine the direction and allocation of food resources within their community. The not-for profit co-operative focuses on creating local food security while providing employment with a liveable wage model providing kitchen employees with wages between $\$ 12-13 /$ hour (Ontario, Canada's minimum wage was $\$ 11.25 /$ hour in 2015). In addition, the co-operative operates a Co-op Cred program, which provides supportive employment opportunities in exchange for credit to purchase healthy groceries provided by community producer members.

The research into the multi-stakeholder co-operative included an examination of the historical records kept by the co-operative as well as a web search for all relevant information pertaining to the organization. The co-operative mission statement identifies its goals: to create a fair, democratic, and meaningful workplace for its workers, as well as an inspiring, community-driven, and welcoming place to shop, learn, and connect consumers within the community. The co-operative sees itself as a resource and partner working with community groups to improve food security and access to good, healthy, real food in their neighbourhood. The co-operative aims to provide the means for people to make empowering food choices and to provide access to fresh, healthy foods for all (On Coop, Mission Statement, 2014). 
The manager was chosen to be the subject of the interview as the manager represents an intermediary between the co-operative board of directors, members and the community stakeholders at large. Managers also have detailed knowledge of the day-to-day operations of the co-operative, which they can call upon during the interview questions.

The semi-structured interview was conducted in a one-on-one setting with the manager. A single interviewer conducted all the interviews. A semi-structured approach was taken to allow the manager to provide additional detail on aspects of the co-operative's operations, and to communicate on any topic on the co-operative business and any additional contextual information that would help our understanding of the co-operative.

The manager of the multi-stakeholder co-operative was interviewed variously between 2013 -2018. The interviews were conducted at the co-operative in a face-to-face interview format. All responses from the interviewee were recorded electronically to ensure accurate capture of responses. One researcher was tasked with collecting the interviews and a second with transcription and analysis of the responses. Responses were also time stamped.

The research was the tenth case in a series of case studies into local food co-operatives in Ontario. The results of the first nine have already been published (Berge et al., 2016) in a range of field studies, which may continue when resources are available. The programme has been conducted utilizing the overall approach found in the Glaser and Strauss (1967) method of four stages of analysis:

1. Comparison of responses to each category.

2. Integrating categories and their associated properties.

3. Delimiting the theory.

4. Writing the theory.

In line with Dye et al. (2000), this initial identification of categories was based on the responses and underwent continuous refinement throughout the data analysis process and continually fed back into identification of the categories. By a process of coding and categorizing responses, we were able to reduce the complexity of the overall responses and organize the responses based on the conceptual nature of the response (Dey, 1993).

The inductive analysis enabled patterns, themes and categories to emerge from the data (Patton, 1990). By coding each response into categories, each statement within a category could be compared for similarities or differences (Dye et al., 2000).

The manager of the multi-stakeholder co-operative was asked questions during the interviews including three themes: Community; Governance; and Co-operative Principles.

\section{The Case Study: Results}

\section{Community}

\section{Membership and boundaries}

The purpose of the community section of questions was to help determine what the co-operative manager considered their community to be. Determining how the multi-stakeholder co-operative and the manager interact within the community further determines the scope of the co-operative's community.

The manager referred to the broader socioeconomic community surrounding the co-operative and not just the cooperative members. "Our community is very socioeconomically diverse and we are trying to respond to that and that is shown in our community partners. We also have producer members and our consumer/eater members are a huge spectrum within that."

\section{Suppliers and their produce}

For the producer member to be considered local they must operate within a $100 \mathrm{~km}$ radius of the multi-stakeholder co-operative. To be considered a family run business the producer member must have indicated within their marketing materials that the organization is a family business or family run. In addition, the members of the board 


\section{Do We Need a New Direction for Managing a Multi-Stakeholder Co-operative? A Critical and Theoretical Reflection on Why Aspirations Sometimes Fail}

of directors or management team of the business must be related. Having examined the 51 producer members that this multi-stakeholder maintains within its supply chain, 23 were considered family run, representing $45 \%$ of the producer membership.

The producer membership represents a wide variety of suppliers to meet the needs of the consumer membership (see Chart 1 -Vendor Types (\%)). The data is presented in percentage format as some producer members provide more than one produce type to the multi-stakeholder co-operative.

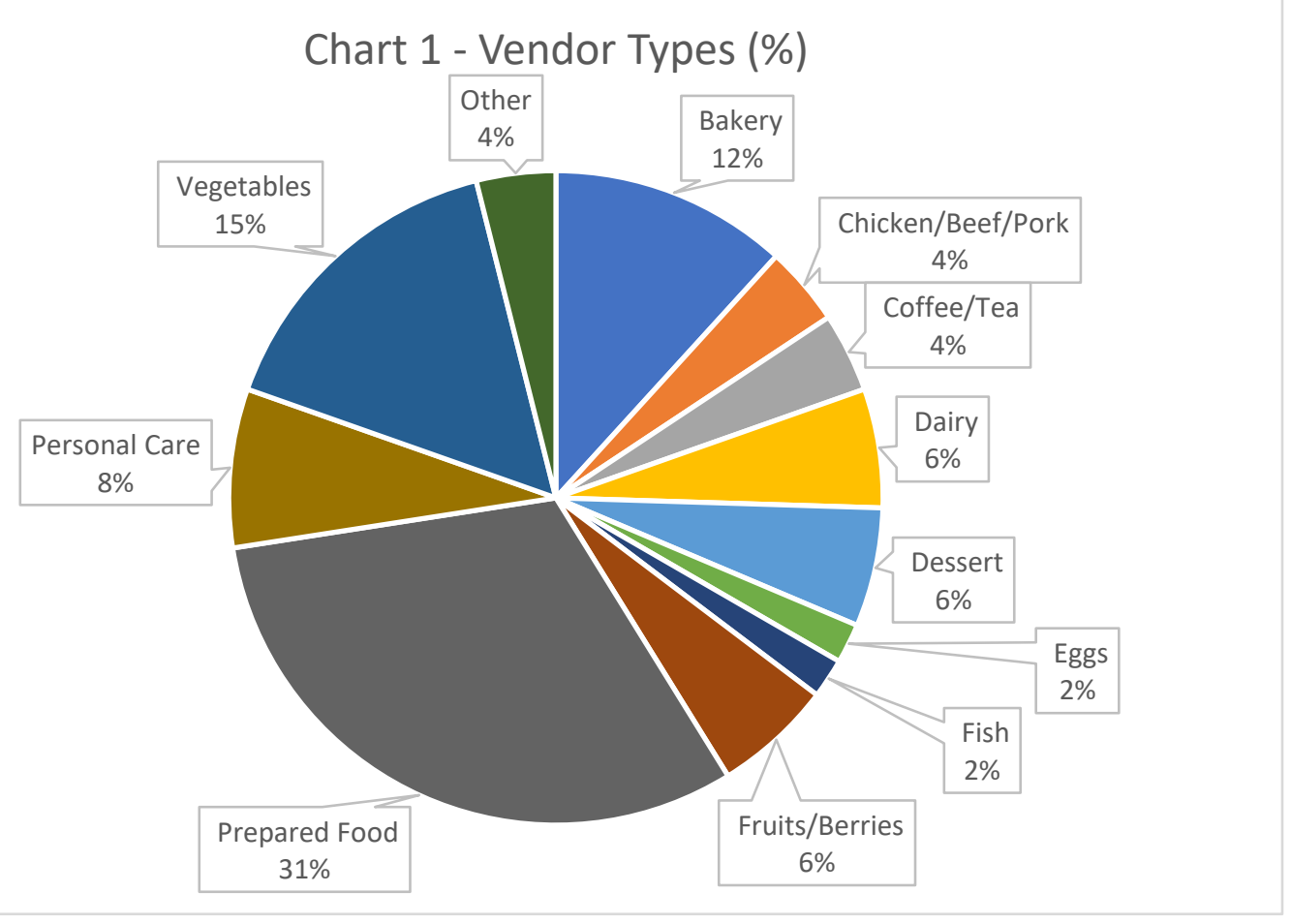

The Community for Consumer Members

The Census District in which the multi-stakeholder is located has a population of 108,805 with a mean age of 40.0 and a median of 38.8 (Statistics Canada, 2018). The neighbourhood profile, which provides a narrower focus on the area where the multi-stakeholder co-operative operates, has a population of 14,974 with a significant working age population ( $25-64$ years) of 9,610 or $64.1 \%$ of the area's population (Social Policy Analysis and Research, 2017). This working population garners a median family income of $\$ 96,956$ (CND). The range in the family income for the community residents put 13\% or 1,940 members under the low income measure (LIM after tax) (Social Policy Analysis and Research, 2017). The LIM after-tax income thresholds for Toronto, Ontario for 1 person is $\$ 22,133$ and for a family of 4 is $\$ 44,266$ (Social Policy Analysis and Research, 2017). The fact that this population has a significant number of households living below the LIM (after tax) is partly due to the unemployment rate of $6.7 \%$ as of 2016, which is better than the City of Toronto unemployment rate of 8.2\% (Social Policy Analysis and Research, 2017).

\section{Worker members}

We also have worker members that are part of our community.

The need to hire from the local community-base was deemed important to the co-operative's mission to create employment opportunities:

Hiring and volunteer recruitment around diversity and representation of diversity of the community. 


\section{Partner organizations}

The final group outlined by the manager as part of the community involved partnering organizations. These organizations included the local recreation and health centre, which worked with the multi-stakeholder co-operative to provide co-op credit as part of the Co-op Credit program that could be redeemed at the co-operative for members that lacked the financial means to purchase food products.

\section{Volunteers}

(Volunteers are not a recognised co-operative stakeholder for governance purposes, but are clearly a recognised community stakeholder)

Community consumer members could work in certain positions within the co-operative and its partners may be paid in co-op credits, which would be used to purchase groceries. The co-op credit program provided supportive employment opportunities allowing unemployed members to participate in the local economy.

\section{Socio-economic change}

Over the last census data collections of 2011 and 2016, the neighbourhood unemployment rate has increased slightly from $6.0 \%$ in 2011 to $6.7 \%$ in 2016; however, this increase is offset by the increased participation rate from $66 \%$ in 2011 to 71.7\% in 2016 (Social Policy Analysis and Research, 2011, 2017). The increased participation rate indicates a growing job market within the neighbourhood. In fact, since 2011, the neighbourhood has undergone a gentrification process that has changed the profile of the original consumer membership of the multi-stakeholder co-operative. The wages provided by the co-operative of \$12-13 (CND)/hour made it difficult for community residents to maintain a home in the neighbourhood. In fact, the gentrification process has led to the closure of the non-profit multi-stakeholder co-operative's retail location as of 2018 due to the increased rental rates.

Lack of synergy between poor members' income and supplier costs and the need for volume Co-operatives focus on their members' needs as the mandate for their organization. Producer or consumer cooperatives focus on cost reduction through increasing purchasing power of the member group they are associated with. The manager suggested the inclusion of community members that have limited means to access the food system was causing conflict as their producer members, i.e. vendors, produce high end products for the gentrified market.

If you think about it, some of our vendors are people that sell at high-end stores or produce much sought after food items, but we are working with people that are having issues around food access.

But there is more than mere access at stake here for the co-operative:

We help to figure out how to have good food accessible to people. Not just subsistence living.

\section{Location}

The multi-stakeholder co-operative purposefully began operations in a marginalized and ill served community within the larger metropolitan centre and as a result the location is considered as partly defining the co-operative community members.

It is a broad community and I think what I would say is that some of that is a result of where we are.

As a result of the increased rental rates the multi-stakeholder co-operative closed its retail and community kitchen location as of July 31, 2018. The co-operative did, however, continue operations through their farmers' market in an attempt to maintain stakeholder relations as the manager believed that the multi-stakeholder co-operative was about operational relations on a direct contact level with membership:

We are about relationships and about having direct links or connections to those stakeholders. 
Do We Need a New Direction for Managing a Multi-Stakeholder Co-operative?

A Critical and Theoretical Reflection on Why Aspirations Sometimes Fail

The role the co-operative plays within its community

Specific mention was made of the role of the co-operative as a bridge between socioeconomic groups.

Our role is figuring out our position in the community. To be relevant to people in the community. Bridge the gap between socioeconomic groups.

The co-operative was considered a location where community members could interact through operational activities providing an opportunity to contribute to the community in general.

"We have an open space. We are a place where people can connect with their neighbours."

"You can have a business and it's a grocery store and I can contribute to it"

"People come to the co-op and get to know people and feel like they are contributing to the community."

"Role is to inspire action in the community, e.g. develop a community garden."

It was good, the manager felt, that consumer members connect to the producer members:

I am really glad you have a relationship with the people you are buying the food from. I want to know exactly who you are getting this from.

To address the need for information requested by the Consumer Members, the manager indicated that the cooperative was working on profiles of the Producer Members.

We are working on profiles for our farmers. - Inform the community, i.e. other stakeholders.

Co-operative interaction with the community

The responses to the question on community interaction were varied including comments on the role of the cooperative as an economic driver within the community and the interaction between different stakeholder groups.

\section{Economic catalyst}

The manager stated that the co-operative represents an economic catalyst at the local level through their purchasing decisions:

We are an economic catalyst by purchasing through small producers.

\section{Operational relationships}

The interaction with the Producer stakeholder group revolved around the operations of the co-operative and occurred through direct interaction with management and staff. 
Table1. Interactions with Producer Stakeholders

\begin{tabular}{|l|l|}
\hline Vendors by category & Interactions \\
\hline Bakery & Daily \\
\hline Chicken & Daily \\
\hline Dairy & Daily \\
\hline Fish & Daily \\
\hline Vegetables & Daily \\
\hline Vegetarian & Daily \\
\hline Fruits/Berries & Bi-weekly \\
\hline Personal Care & Monthly \\
\hline Tea & Monthly \\
\hline Other & Monthly \\
\hline Coffee & Weekly \\
\hline Dessert & Weekly \\
\hline Eggs & Weekly \\
\hline Prepared Food & Weekly \\
\hline Sauces/Dressing & Weekly \\
\hline
\end{tabular}

In fact, during one interview, Producer stakeholders from the bakery category interrupted the interview to discuss the delivery with the manager and future plans for production. This particular Producer delivered all their goods on a daily basis to the multi-stakeholder co-operative via bicycle. Interaction with the Producer stakeholders was further clarified as the co-operative manager indicated that there was a requirement to treat primary producers differently than local value added producers in terms of their economic responsibilities within the co-operative community.

\section{Shared Spaces}

The multi-stakeholder co-operative provides many outlets for the community and the various stakeholders to interact through their operations including a community shared orchard, a community kitchen, and community shared garden.

We are trying to figure out the renting. We are probably going to have two tiers of farmer producers that are producer members that get a certain rate and then a local person wanting to run a business gets a higher rate.

The activities outlined by the co-operative manager during the interview process were compared to the cooperative's documentation on standard operating procedures, mission statement and websites to ensure the validity of the interpretation of the programs by the manager.

\section{Common Activities}

The activities outlined by the manager include interactions between stakeholder groups such as seasonal planning activities between Producer and Consumer Members.

"Producer Membership - planning a growing season with set prices."

"Communicate with Eater Members that these are the farmers we (the co-operative) are working with, this is the product and how they grow it and we can have a secure supply."

From the communications with, and between, the various stakeholder members the co-operative developed activities within the community kitchen to assist in the use of the Producer Members products. These communications were not part of the overall governance of the co-operative, but part of the operational relationships developed by the manager and staff of the co-operative with the various stakeholder groups. 


\section{Do We Need a New Direction for Managing a Multi-Stakeholder Co-operative? A Critical and Theoretical Reflection on Why Aspirations Sometimes Fail}

When the manager is referring to planning a growing season or securing a supply, he is not referring to formal policy setting by the co-operative, but informal communication between management and stakeholder groups via operational interactions. As a result of these operational interactions, programs were developed to address changing stakeholder needs. For example:

Community canning project was in response to a bumper year for farmers, providing an outlet for their products.

In addition to the interactions outlined between producer and consumer members via management within the multi-stakeholder co-operative, the manager highlighted the co-op credit program with their recreation and health centre partners. The manager also indicated that there was a need to expand the credit co-op program.

\section{Conflict between social goals and economic costs}

At times the multi-stakeholder co-operative enacted programs or services that would not be considered sound business decisions. The manager indicated that community impact represented an overriding focus to decisions before strict profit maximization.

Some decisions taken are sometimes not considered as financially viable but, as a result of compromises, they always look at the bigger picture of having a greater impact on the community.

The final point when speaking to community outlined the need for the larger co-operative community to interact together to provide support to producers, which in turn would provide affordable food to those community members unable to access the food system. The manager ended the discussion on community with a statement indicating their feeling of responsibility to community members in general.

There is the need for co-operatives to share support especially in struggles that they go through. It's really a hard place to be in but there is lots of space for support especially for food co-ops. The reality of people not being able to afford it. Lots of compromise for young farmers as well looking at realistic prices where they can pay their bills. We are constantly compromising. I have sacrificed many, many hours. I feel very much like we are responsible for people.

\section{Governance}

The role of the Board of Directors in the governance of the multi-stakeholder co-operative Even though the multi-stakeholder co-operative had been in operation since 2008, at the time of the first interview (2013), the governance structure had not fully been solidified. Notwithstanding, the Board members are key actors with the authority to enact policy and make program decisions.

..... twelve members on the board representing the interest of the subgroups that comprise the co-op. ........ there are Worker members, Producer members and Eater members on the board.

The manager did express this was still a development phase, with the co-operative governing board described as being very young, and needed more interaction by the board at the operational level of the co-operative.

Governance is still in early phase requiring more direct influence by the board of directors on co-operative operations.

Responding to the governance structure the manager indicated that it is an ongoing adaptation to the various needs of the stakeholder groups through representation on the board.

"The governance structure had not been firmed up fully; workers, producers, eaters were adequately represented on the board". 
"For worker member stakeholders, the most common and important benefit to them is to be part of the decision-making process."

"They (the co-operative) have monthly meetings that encourage participation and staff decision making".

The top 3 governance issues facing the co-operative

The manager felt the top three most pressing governance problems are:

1. Membership definition - what qualifies one to be a member and benefits attached to membership.

2. By-laws - what should be contained in the by-laws of a multi-stakeholder co-operative business?

3. Exclusivity of member services - should the store be patronized by only members.

Lack of a solid governance structure could explain the importance of operational relationships between management and stakeholders in determining the direction of the co-operative. It should be noted, however, that the governance of the co-operative was of sufficient capacity to formalize the mission, vision and values of the cooperative. The strategic planning of the co-operative was managed by the board of directors through the democratic process found in the ICA statement of co-operative principles.

\section{The Co-operative Principles}

The role of membership in the governance of the multi-stakeholder co-operative

The manager identified the Democratic Member Control principle as the most important co-operative principle.

For me, Democratic Member Control differentiates co-ops from being a non-profit that could do most of what we do. It is why we wanted community stakeholders.

It was also identified as the most difficult principle to implement in the context of a large membership with only $6 \%$ of the membership actively participating in the annual general meeting. The manager felt this formal approach to member participation limits participation through defined date, time and location criteria.

In the manager's view there is far greater participation in the purpose of the multi-stakeholder co-operative through regular operational interactions between the management and membership. It is this operational participation within the co-operative that guides the operations of the co-operative more so than the broader governance policies. It appears that the manager's daily interactions with the membership are converted into operational criteria/programs, while the board of directors provides guiding policies focused on strategic plans for the cooperative.

"The board plays a very important role. By-law changes are their responsibility. Right now, we are trying to determine what the by-laws should contain. "

"People come to the co-op and get to know people and feel like they are contributing. The spaces the co-operative provides are there to engage the community in the co-operative. The producers use the community kitchen to produce value added products. Our role (meaning management) is figuring out our position in our times to be relevant to people."

However, these informal opportunities for membership inputs had become very restricted. As of 2018, the only operations currently running through the multi-stakeholder co-operative is the farmers' market. This operation focuses the co-operative stakeholders' direct interactions between the producers and consumers as individual transactions. It was not clear how this data was being codified to inform the co-operative on its future direction.

\section{The Case Study: Analysis}

What is clear is the dedication of the manager and importance placed on the social relational aspects of the cooperative but even here the economics of food security and food justice for the poor comes across strongly in the interview as a primary goal for the co-operative. Given the small size of the leadership team (manager and board), 


\section{Do We Need a New Direction for Managing a Multi-Stakeholder Co-operative? A Critical and Theoretical Reflection on Why Aspirations Sometimes Fail}

clearly their shared commitment to the ideals of co-operative ownership and governance are key motivators for all the stakeholder group representatives. We might suggest that, on the evidence of the case, if democratic control was the manager's most important co-operative principle, care for the community ran a close second. This multistakeholder co-operative's focus on bringing consumer, worker and producer together whilst reaching out to others in the community to build an alternative local economy puts them within that tradition of the North American cooperative vision espoused by Keen (1949).

Given the consumer membership, calculated on the figures provided, of around 600, the co-op's retail market share was potentially around $4 \%$ of the total population. With the main focus of the multi-stakeholder co-operative on social justice concerns such as food access, the $4 \%$ retail market share was represented by the poorest, most marginalized members of the community. As a result of the profile of the retail market share held by the multistakeholder co-operative, the leadership developed food access programs that measured success not in traditional food retail terms, e.g. revenue streams and annual food expenditure. Such traditional measures would show the multi-stakeholder co-operative as clearly underperforming. After 5 years of trading (2013) to have a revenue stream (not surplus) of $\$ 50,000 \mathrm{CDN}$, meant an average spend per member of just under $\$ 84 \mathrm{CDN}$ per annum (p.a). This measure does not, however, take into account the volunteer food access program provided by the multi-stakeholder co-operative, which provided food for volunteer hours. It is unfortunate that the notoriously low margins on food along with the inclusion of a program providing alternative access to food which did not require the member to open their wallets meant that the co-operative was not able to capture a sufficient percentage of the cash within their members' wallets. As a result, the co-operative presents a poor traditional revenue picture where estimates of their low income members' spending should be over $\$ 22,000$ CDN p.a., or a potential annual expenditure on food of around $\$ 3,300$ CDN per member (around 15\% of total income based on Canadian Food Survey data for low income consumers, 2016). This would represent a conservative estimate, assuming that not all co-op members would be in the LIM income bracket, and that many members would have families with possibly dual incomes. Based on these traditional calculations, had this estimated revenue stream been achieved, it would have produced an annual revenue stream close to $\$ 2 \mathrm{~m}$ CDN p.a. The multi-stakeholder co-operative in this case study, however, chose to focus on a specific group within the retail market space, the poor. As a result, full advantage was not taken of the potential revenue stream within the market environment.

In the UK, the average shopper purchases around 41 items in their weekly supermarket shop according to Kantar Retail (Guardian, 30.01.2015). Assuming a broadly similar lifestyle in Canada to that of the UK, the Food Cooperative's offering of 12 product lines would suggest that members on whatever income would be hard pressed to find more that 15-18 items per week assuming duplication of some products in the prepared foods line. But given that access to the 15-18 items was given without cash transactions, the co-operative allowed revenues we estimate of around $\$ 1 \mathrm{~m} C D N$ to be underreported. As a result, the co-operative appears to have badly underperformed based on traditional measures.

Gentrification was probably more of an opportunity than a threat from the standpoint of the local high quality food producers; hence the continued sustainability of the Farmers' Market. A local retailer selling local healthy and sustainable produce at premium prices might have been an attractive prospect if it were not for the focus of the multi-stakeholder on social justice issues over revenues. Clearly such a strategy would have failed to meet the cooperative founders' vision. But it could have provided a viable co-operatively owned and democratically controlled producers co-op retail business, consolidating the local market for its high value added producer members and providing decent employment opportunities for its worker members and sustainable products and healthy products for the average consumer in their local community. For the founders, bringing together the whole community, including the marginalized poor, was the objective. But it is an aspiration that has to be realisable and one that clearly creates challenges and requires resourcing. Such a project needs to be part of the medium-term vision. The co-operative did not build on its strengths but instead it tried to start at the beginning with a model that should have been something it was aiming for, incrementally, down the line. Such a strategy would not hurt the LIM community, who now clearly have no store and cannot afford the Farmers' Market. A store with a potential throughput of even $\$ 1 \mathrm{~m}$ CDN could have provided alternative access to food through innovative programs that did not completely eliminate a revenue stream, e.g. cut prices in the last hour for perishable goods. The store could, via Corporate Social Responsibility programmes, have supported a refuge for the homeless, supported/partnered with other local anti- 
poverty and environmentalist NGOs and local health units. Most importantly it could have been an organisation with a mission that now had resources to work out the next steps. This, of course, is speculation. But five facts do stand out from the case study:

a) The motivation for founding the multi-stakeholder co-operative was to provide for locally based food security, economic democracy and distributive justice grounded in sustainable and healthy production and consumption held together by a profound sense that community solidarity is a critical element in determining human well-being.

b) After 5 years of trading they had a revenue stream of $\$ 50,000$ CDN indicating the average spend per member was less than $\$ 84.00$ p.a. as a result of underreporting social spending on alternative access to food for the marginalized population within their community.

c) Despite their effort and focus on stakeholder relationships and governance, formal participation in this process is recorded to be around $6 \%$ of the total membership.

d) The co-operative was forced to close their retail store. This indicates that, given the low spend per member, although their 51 producer members' informal links were clearly good, only a very narrow band of the consumer members spent cash in the store regularly enough for this informal channel of participation to provide adequate feedback that ideally should have been possible with around $4 \%$ of the total population in membership.

e) It appears that of the original initiatives, i.e., a Retail Shop, Community Canning, Community Shared Orchard and a Farmers' Market, only the initiatives linked to the Farmers' Market were viable. The Community Canning initiative relied on the Retail Shop's infrastructure which could not be sustained due to increased rental costs. The Community Shared Orchard remains linked to the Farmers' Market allowing it to survive gentrification without adaptation of their operations.

So are the co-operative's goals misguided? It is the firm conviction of the authors of this paper that the answer is emphatically no. Climate change increasingly makes sense of greater simplification in consumption and local economic development, particularly in food. The levels of dependency, marginalization, debt and poverty even in developed economies like Canada and the UK coupled to increasing economic polarization adds fuel to the case for a co-operative business model that emphasizes economic democracy, inclusivity, community and distributive justice. So we need to repeat the question put by the former economist and Professor Emeritus at Cornell University, Jaroslav Vanek:

\section{It has always puzzled me how it could have been possible that a productive organization based on co-operation, harmony of interests and brotherhood of men, so appealing and desirable on moral and philosophical grounds could have done so poorly when subjected to a practical test. (Vanek, J, 1975, p. 446)}

What might we deduce from these results? That with participation in the governance processes so low, members from all parts of the co-operative supply chain plus their worker members clearly could not be used as the sole sources of information on member needs. Whilst regular informal discussions with suppliers are vital, the conversation has to be informed by customer needs as an immediate priority for informing strategy. But towards what goals and values is the question (Burgoyne, 1995). Clearly socioeconomic and environmental contexts point to co-operation with a bias to the poor and sustainable economics. But strategy needs time, resources and milestones on the way to the achievement of goals. The manager was correct in trying to build constructive information flows on the basis of operational relationships. Burgoyne's model of the interface between organizational boundary workers, in this case the manager and staff at the retail store, is a crucial information gathering process. But the information from 51 producer members, who were part owners of the co-op, appeared to contradict the goal the manager was firmly committed to. The data received from regular customers at the store was inadequate. They must have represented, given the figures, a tiny minority of consumer enthusiasts and a handful of mostly volunteer staff. This could not be considered a reliable data source for the wider needs of 600 members let alone the 14000+ potential members in their local community. The fledgling co-operative recruited something like $4 \%$ of its geographical population into membership but did not engage by reaching out and listening 


\section{Do We Need a New Direction for Managing a Multi-Stakeholder Co-operative? A Critical and Theoretical Reflection on Why Aspirations Sometimes Fail}

beyond what in governance and probably commercial terms was $6 \%$ or 36 members out of 600 . In turnover terms, the silent $94 \%$ of its membership appear hardly to trade at all with their co-operative.

\section{Conclusion}

In a globalised distribution system, where North America is one of the most technologically and, in marketing terms, sophisticated distribution systems in the world, the data the co-operative needed to build a viable business was not available to it based on their operational intelligence. Secondly, if you are starting from scratch, you must have an incremental strategy towards realizing your vision. While there is a market for healthy eating amongst average consumers, the lowest paid have to buy cheap. But to sell cheap, or give away through volunteer access programs, requires a guaranteed high throughput. The capitalists provide cheap food because they need these exploited folk to have the energy to work for them and they have the intelligence to make sure their poor quality food at least tastes reasonable and is supported by intense market research and sales strategies.

The Rochdale 1844 store succeeded because the limited range met members' needs, they sold at retail prices and let us remember they were not competing with a multinational retailer or McDonald's. The authors of this paper are not retailers, but we do make the claim that a staged strategy to achieve the vision demonstrated in the case study is possible. Research needs to focus on developing a grassroots local economy model that works without government or big capital investments, to meet the principle of Autonomy. On the case study experience, the model includes mobilizing local small farm producers into a co-operative to distribute their produce locally, develop a retail store with a capacity to sell surpluses farther afield and consider food processing as a later stage in development. Having established a viable locally owned food industry, linking local producers with local consumers will be the time to study barriers to inclusion that are relevant to the poor and marginalized in their area and a model that lower income group members can take ownership of. Local producers have capacity and management skills and there will be a local consumer segment who have the motivation (and self interest) and income to pay a premium price. The quality of local production cannot be duplicated in a supermarket chain. On the solid basis of local economic success and community solidarity, we can look for strategies to reach out and mobilize the economically marginalized. Whether this stage is reached and success achieved may well depend on how actively engaged members, managers and employees within the co-operative are from the start with co-operative values, principles and vision at the level of cultural reproduction. Arguing for co-operative servant leaders drawn in the main from ethically motivated professional and middle class people may be politically incorrect today in a movement constantly emphasizing grass roots democratic control but it remains historically accurate (Schaffer, Jack, 1999) and practically necessary.

The case study surely had such a servant leader in its manager, yet it still failed. The case demonstrates that if visions are to become realities, co-operators must first clearly understand that whilst vision can form the goals, economic and social realities must inform the incremental strategies going forward. This is not to argue for postponing cooperative values and principles for they must inform the lived organizational and associational culture from the outset, otherwise, as we see today in co-operatives the world over, vision can turn all too easily into a complacent bureaucracy.

\section{References}

Ackoff, R. L. (1981). Creating the corporate future : plan or be planned for. New York: Wiley.

Basterretxea, I, Cornforth, C. \& Heras-Saiarbitoria, I. (2020). Corporate governance as a key aspect in the failure of worker co-operatives, Economic and Industrial Democracy, 1-26, Sage. DOI: 10.1177/0143831X19899474

Ben-Ner, A., \& Putterman, L. (1999). Values and Institutions in Economic Analysis. In A. Ben-Ner \& L. Putterman (Eds.), Economics, Values, and Organizations (pp. 243-266). Cambridge: Cambridge University Press.

Berge, S., Caldwell, W., \& Mount, P. (2016). Governance of Nine Ontario Food Co-operatives, Annals of Public and Co-operative Economics, CIRIEC, Published by John Wiley \& Sons Ltd, Oxford.

Brym, R. J., \& Sacouman, R. J. (1979). Underdevelopment and social movements in Atlantic Canada. Toronto: New Hogtown Press. 
Burgoyne, J. (1995). "Feeding minds to grow the business", People Management, September, pp. 22-28.

Davis, P. (1999). Managing the Co-operative Difference. A survey of the application of modern management practices in the co-operative context. Co-operative Branch, International Labour Office, Geneva. ISBN 92-2-111582-8

Davis, P. (2001). The governance of co-operatives under competitive conditions: Issues, processes and culture. Corporate Governance, 1(4), 28-39.

Davis, P. (2004). Human Resource Management in Co-operatives, ILO, Geneva, pp191. ISBN 92 -2-114329-5

Davis, P. (2014). 'Retrieving the Co-operative Value-Based Leadership Model of Terry Thomas' Journal of Business Ethics, Vol. 125, No 4, December, Springer. 12 pages. DOI 10.1007/s10551-014-2489

Davis, P. (2018a). Ch. 6 Leadership as a Profession: A Special Case Dependent on Organisational Ownership, Governance, Mission and Vision, in Professionalizing Leadership Debating Education, Certification and Practice Edited by Anders Ortenblad, Palgrave Macmillan. ISBN 978-3-319-71784-5

Davis, P. (2018b). Ethical agency contracts as a basis for co-operative management and leadership, International Journal of Co-operative Accounting and Management, Vol.1 No. 1, Sobey School of Business, Saint Mary's University.

Dey, I. (1993). Qualitative data analysis : a user-friendly guide for social scientists. London: New York, NY : Routledge.

Donaldson, T., \& Preston, L. E. (1995). The Stakeholder Theory of the Corporation: Concepts, Evidence, and Implications. The Academy of Management Review, 20(1), 65-91.

Dye, J., Schatz, I., Rosenberg, B., \& Colemand, S. (2000). Constant comparison method: a kaleidoscope of data. The Qualitative Report, 4.

Edvinsson, L. \& Malone, M. S. (1997) Intellectual Capital, Piatikus, London.

Evan, W. M., \& Freeman, R. E. (1988). A stakeholder theory of the modern corporation: Kantian capitalism. In T. Beauchamp \& N. Bowie (Eds.), Ethical theory and business (pp. 75-93). Englewood Cliffs, NJ: Prentice Hall.

Fairbairn, B., MacPherson, I., \& Russell, N. (2000). Canadian co-operatives in the year 2000: memory, mutual aid, and the millennium. Saskatoon: Centre for the Study of Co-operatives, University of Saskatchewan.

Gide, C. (1922). Consumers' co-operative societies. New York: Alfred A. Knopf Inc.

Glaser, B. G., \& Strauss, A. L. (1967). The discovery of grounded theory: strategies for qualitative research. Chicago: Aldine Pub. Co.

Granovetter, M. (1983). The Strength of Weak Ties: A Network Theory Revisited. Sociological Theory, 1, $201-233$.

Goedhart, G.J.D.C. (1928). The Moral Aspect of Co-operation. Review of International Co-operation Vol. 88 , No.2 Centennial Edition, Geneva 1995, 7-10.

Gupta, R. (2018). High rents contribute to closure. Retrieved from https://www.toronto.com/news-story/8681778high-rents-contribute-to-closure-of-parkdale-s-west-end-food-co-op/

Kantar Retail (2015) quoted in the Guardian, 30.01 .2015 https://www.theguardian.com/business/2015/jan/30/tesco-cuts-range-products

Keen, G. (1949). The birth of a movement, reminiscences of a co-operator: United Co-operators of Canada Collection.

Lund, M. (2011). Solidarity is a Business Model: A Multi-Stakeholder Cooperatives Manual. Retrieved from http://www.uwcc.wisc.edu/pdf/multistakeholder\%20coop\%20manual.pdf

MacPherson, I. (1979). Each for all: a history of the co-operative movement in English Canada, 1900-1945. Toronto: Macmillan of Canada in association with the Institute of Canadian Studies, Carleton University.

Mercer, T. W. (1931 reprinted in 1995). Foundations of Co-operation. Rochdale Principles and Methods, Review of International Co-operation, Vol. 88, No 2.

Neto, S. B. (2012). Economics and Management of Cooperative Organisations, Atlas, Sao Paulo.

Nonaka, I. \& Takeuchi, H. (1995). The Knowledge-Creating Company: How Japanese Companies Create the Dynamics of Innovation. Oxford University Press, New York.

On Co-op. (Editions 2013 /4). Our Mission. Retrieved from www.ontario.coop/about us/our mission

Patton, M. (1990). Qualitative evaluation and research methods. Newbury Park, Calif.: Sage Publications.

F.W. Raiffeisen, 1818 -1888 (undated English translation). Deutscher Raiffeisenverband e. V., Adenauerallee 127, 5300 Bonn 1 Germany.

Rudin, R. (1990). In whose interest? : Quebec's Caisses populaires, 1900-1945. Montreal [Que.]: McGill-Queen's University Press.

Sacchetti, S., \& Sugden, R. (2003). The Governance of Networks and Economic Power: The Nature and Impact of Subcontracting Relationships. Journal of Economic Surveys, 17(5), 669-692. 
Sacchetti, S., \& Torita, E. (2014). The social value of multi-stakeholder co-operatives: The case of the CEFF system in Italy. In T. Mazzarol, S. Reboud, E. Limnios, \& D. Clark (Eds.), Research Handbook on Sustainable Cooperative Enterprise: Case Studies of Organizational Resilience in the Co-operative Business Model, 285-300. Northampton, MA, USA: Edward Elgar.

Sacchetti, S., Tortia, E., \& Tortia, E. (2016). The Extended Governance of Cooperative Firms: Inter-Firm Coordination and Consistency of Values. Ann. Public Coop. Econ. Annals of Public and Cooperative Economics, 87(1), 93116.

Sacchetti, S., \& Tortia, E. C. (2008). Dall organizzazione multi-stakeholder all impresa reticolare. Impresa Scoiale, 77(4), 104-124.

Sacconi, L. (2011). Multi-stakeholder Governance for Effectively Sharing Social Responsibility. Econometica.

Shaffer, Jack (1999). Historical Dictionary of the Cooperative Movement, Historical Dictionaries of Religions, Philosophies and Movements, No 26, The Scawcrow Press, Lanham, Md., \& London. ISBN 0-8108-3666-1

Social Policy Analysis and Research. (2011). 2011 Neighbourhood Census. Retrieved from https://www.toronto.ca/ext/sdfa/Neighbourhood\%20Profiles/pdf/2011/pdf4/cpa86.pdf

Social Policy Analysis and Research. (2017). 2016 Neighbourhood Profile. Retrieved from https://www.toronto.ca/ext/sdfa/Neighbourhood\%20Profiles/pdf/2016/pdf1/cpa86.pdf

Statistics Canada. (2018). Census Profile 2016. Retrieved from https://www12.statcan.gc.ca/censusrecensement/2016/dp-

pd/prof/details/page.cfm?Lang=E\&Geo1=FED\&Code1=35081\&Geo2=PR\&Code2=35\&Data=Count\&Search Text=Parkdale-High\%20Park\&SearchType=Begins\&SearchPR=01\&B1=All\&GeoLevel=PR\&GeoCode=35081\&TABID=1

Survey of Household Spending in Canada, 2016. https://www150.statcan.gc.ca/n1/dailyquotidien/171213/dq171213b-eng.htm

Turnbull, S. (1997). Stakeholder Cooperation. Journal of Co-operative Studies, 29(3), 18-52.

Vanek, Jaroslav, (1975). The Basic Theory of Financing of Participatory Firms, in Self Management, Penguin Moder Economic Readings, London.

Zamagni, S. (2012). The Impact of Co-operatives on Social Capital and Civicness. Paper presented at the European Research Centre for Co-operative and Social Enterprises: Promoting the Understanding of Co-operatives for a Better World, Venice, San Servolo. 